\title{
High-resolution carbon isotope records of the Toarcian Oceanic Anoxic Event (Early Jurassic) from North America and implications for the global drivers of the Toarcian carbon cycle
}

T.R. Them II ${ }^{\mathrm{a}, \mathrm{b},{ }^{*}, \text { B.C. Gill }}{ }^{\mathrm{a}}$, A.H. Caruthers ${ }^{\mathrm{c}, \mathrm{d}}$, D.R. Gröcke ${ }^{\mathrm{e}}$, E.T. Tulsky ${ }^{\mathrm{a}}$, R.C. Martindale ${ }^{\mathrm{f}}$, T.P. Poulton $^{\mathrm{g}}$, P.L. Smith 


\begin{abstract}
The Mesozoic Era experienced several instances of abrupt environmental change that are associated with instabilities in the climate, reorganizations of the global carbon cycle, and elevated extinction rates. Often during these perturbations, oxygen-deficient conditions developed in the oceans resulting in the widespread deposition of organic-rich sediments these events are referred to as Oceanic Anoxic Events or OAEs. Such events have been linked to massive injections of greenhouse gases into the ocean-atmosphere system by transient episodes of voluminous volcanism and the destabilization of methane clathrates within marine environments. Nevertheless, uncertainty surrounds the specific environmental drivers and feedbacks that occurred during the OAEs that caused perturbations in the carbon cycle; this is particularly true of the Early Jurassic Toarcian OAE $(\sim 183.1 \mathrm{Ma})$. Here, we present biostratigraphically constrained carbon isotope data from western North America (Alberta and British Columbia, Canada) to better assess the global extent of the carbon cycle perturbations. We identify the large negative carbon isotope excursion associated with the OAE along with high-frequency oscillations and steps within the onset of this excursion. We propose that these high-frequency carbon isotope excursions reflect changes to the global carbon cycle and also that they are related to the production and release of greenhouse gases from terrestrial environments on astronomical timescales. Furthermore, increased terrestrial methanogenesis should be considered an important climatic feedback during Ocean Anoxic Events and other similar events in Earth history after the proliferation of land plants.
\end{abstract}

Keywords: Toarcian Oceanic Anoxic Event; Early Jurassic; carbon cycle; terrestrial methanogenesis; abrupt climate change 


\section{Introduction}

The Early Jurassic Toarcian Oceanic Anoxic Event (T-OAE) represents a time of severe global environmental change that is associated with a major extinction of marine organisms (e.g., Harries and Little, 1999; Caruthers et al., 2014; Danise et al., 2015), widespread deposition of organic-rich sediments (Jenkyns, 1988), and large-scale perturbations to the global carbon cycle recorded as carbon isotope excursions or CIEs (e.g., Hesselbo et al., 2000). To date, the large negative CIE has been recognized in organic carbon, carbonate carbon, and fossil wood, confirming that the carbon cycles in the marine and terrestrial realms were affected during the TOAE (Fig. 1) (e.g., Hesselbo et al., 2000). While some studies have identified a T-OAE CIE of up to $-8 \%$ in magnitude in bulk organic and carbonate carbon, studies of compound specific biomarkers indicate the absolute global magnitude of the CIE as only $-3 \%$ to $-4 \%$ o (Schouten et al., 2000; French et al., 2014; Suan et al., 2015). U-Pb age dates around the T-OAE CIE estimate its duration to be $\sim 300 \mathrm{kyr}$ around $183.1 \mathrm{Ma}$ (Sell et al., 2014), which is comparable to an earlier estimate that has higher uncertainties on the ages (Kemp et al., 2005) and a recent age model based on orbital tuning that suggests a duration of $500 \mathrm{kyr}$ (Boulila et al., 2014). These estimated timeframes are similar to that of the CIE associated with the much younger PaleoceneEocene Thermal Maximum (PETM; ca. 55.8 Ma) (Cohen et al., 2007). The PETM is hypothesized to have been the result of a massive transitory release of carbon to the oceanatmosphere system via marine clathrate destabilization, volcanic outgassing, oxidation of organic matter, increased terrestrial methane cycling, or a combination of these drivers (Dickens et al., 1995; Svensen et al., 2004; Higgins and Schrag, 2006; Pancost et al., 2007; Panchuk et al., 2008). Similar forcings have also been implicated for the Toarcian OAE (e.g., Hesselbo et al., 
2000; McElwain et al., 2005; Svensen et al., 2007; Beerling and Brentnall, 2007; Pieńkowski et al., 2016).

High-resolution sampling over the falling limb of the T-OAE CIE has identified smallscale CIEs - described by some authors as abrupt steps or oscillations of $\sim 1-2.5 \%$ in magnitude - recorded in organic and carbonate carbon and fossil wood at several geographic locations in the Tethys and Boreal seas (Fig. 1; Kemp et al., 2005; Hesselbo et al., 2007; Hermoso et al., 2009; Hesselbo and Pieńkowski, 2011; Hermoso et al., 2012). These small-scale CIEs have been interpreted to represent discrete methane clathrate destabilization events tied to astronomically forced changes to the global climate (Kemp et al., 2005; Hesselbo and Pieńkowski, 2011; Hermoso et al., 2012) (Fig. 1).

The temporal association of the T-OAE with the emplacement of the Karoo-Ferrar large igneous province (LIP) (Pálfy and Smith, 2000; Svensen et al., 2007; Caruthers et al., 2014; Sell et al., 2014; Burgess et al., 2015) has led to the proposition of a causal correlation of these events to the CIE through injection of mantle-derived carbon dioxide $\left(\mathrm{CO}_{2}\right)$ into the atmosphere. This scenario would lead to a cascade of synergistic environmental feedbacks, including global warming, increased precipitation and weathering, ocean anoxia and acidification, and marine extinctions (Caruthers et al., 2014; Bond and Wignall, 2014). Importantly, Ferrar sills intrude through coal seams, which may have released additional methane and carbon dioxide into the atmosphere (McElwain et al., 2005; Svensen et al., 2007).

Although some studies have challenged the global nature of the Toarcian carbon cycle perturbations (e.g., Wignall et al., 2006), new geochemical records from outside European Boreal and Tethyan regions support the global extent of the T-OAE CIE; it has now been 
45 documented in Argentina (Al-Suwaidi et al., 2011), the Arctic (Suan et al., 2011), British 46 Columbia (Caruthers et al., 2011, 2014), Japan (Gröcke et al., 2011; Kemp and Izumi, 2014), and

47 more recently China (Fu et al., 2016) (Fig. 1). The small-scale CIEs observed in the falling limb 48 of the T-OAE CIE in records from Europe (Fig. 1) have not been documented at these new 49 localities due to low sampling resolution; therefore, it is uncertain whether these small-scale 50 CIEs are truly the reflection of global scale processes, or whether they were potentially driven by 51 local process (e.g., Pittet et al., 2014). However, a recent study of $\delta^{13} \mathrm{C}$ of fossil wood from 52 Europe suggests that these small-scale CIEs also occurred in atmospheric carbon dioxide and 53 were thus global phenomena (Hesselbo and Pieńkowski, 2011). Understanding the nature and 54 extent of the small-scale CIEs is imperative for distinguishing these carbon-isotope excursions as 55 either global events or as byproducts of regional oceanographic or tectonic processes. Herein, we present biostratigraphically-constrained, high-resolution, organic carbon

57 isotope $\left(\delta^{13} \mathrm{C}_{\text {org }}\right)$ records from two western North American sites that were located in eastern 58 Panthalassa during the Early Jurassic (Figs. 1, 2 and 3). These data constitute the most detailed 59 carbon isotope record of the T-OAE and surrounding intervals outside the European region. 60 Taken together, the data reveal that small-scale CIEs on the falling limb of the large T-OAE CIE 61 were, in fact, global phenomena, providing strong evidence for multiple global carbon cycle 62 perturbations across the T-OAE CIE.

\section{2. Study locations}

The Fernie Formation of Alberta and British Columbia comprises Jurassic strata 66 deposited in the Western Canada Sedimentary Basin. The Fernie Formation crops out in the 67 foothills of the Canadian Rocky Mountains and is present in the subsurface to the north and east, 
and the Pliensbachian to Aalenian interval has been identified in outcrops and drill cores utilizing ammonite biostratigraphy (Hall, 1984; Poulton and Hall, 1993; Asgar-Deen et al., 2003).

We present a section of the Pliensbachian and Toarcian interval of the Fernie Formation located along East Tributary of Bighorn Creek located at Ya Ha Tinda Ranch, Alberta. At the East Tributary section, the Pliensbachian and Toarcian stages consist dominantly of organic-rich, calcareous mudstones and siltstones of the Red Deer and Poker Chip Shale (PCS) members of the Fernie Formation (Fig. 2). Jenkyns (1988) considered the PCS to be the lithologic expression of the T-OAE in his global compilation of Early Jurassic organic-rich facies, though the resolution of the biostratigraphic data was insufficient to definitively link the PCS to the T-OAE. The diverse ammonite assemblages preserved in the East Tributary succession broadly indicate the late Pliensbachian to middle Toarcian ages (Hall et al., 1998) and provide the framework for global correlation of our geochemical records (Fig. 2). We cannot disclose the precise location (GPS coordinates) of the East Tributary section because it is a fossil-bearing locality and is protected under the Canadian National Parks Act. However, inquiries about the site for scientific investigation can be directed to Parks Canada or the Royal Tyrrell Museum of Palaeontology in Drumheller, Canada; the East Tributary of Bighorn Creek is Royal Tyrrell Museum of Palaeontology Locality \#L2428.

We also provide a high-resolution $\delta^{13} \mathrm{C}_{\text {org }}$ record from a site located on the Yakoun River on Graham Island in Haida Gwaii, western British Columbia, where the T-OAE CIE has been previously identified (Caruthers et al., 2011, 2014). Here, the stratigraphic interval that contains the Toarcian is found in the Whiteaves Formation of the Maude Group. The portion of the Whiteaves Formation which contains the CIE interval consists predominately of siltstones and mudstones with organic carbon contents of up to $2 \%$ (Caruthers et al., 2011). The Haida Gwaii 
91 sequence was deposited in a relatively open-ocean environment on the allochthonous Wrangellia

92 Terrane in northeastern Panthalassa (Smith, 2006), but its original position with respect to North

93 America is enigmatic (Caruthers et al., 2011, 2014).

\section{Methods}

\subsection{Ammonite collection}

All ammonite specimens from the East Tributary section are curated at the Royal Tyrrell Museum of Palaeontology in accordance with provincial laws. Full details of fossil preparation or consolidation for each specimen are recorded in the Royal Tyrrell Museum of Palaeontology specimen database. All fossils and geological samples were collected under a Parks Canada

101 collection and research permit (\#YHTR-2014-16156) and fossil excavation permits from the 102 Alberta Government (RTMP Permit \#13-058, \#14-009, and \#15-019).

\section{$103 \quad 3.2$ Geochemical analyses}

Hand samples were initially collected from the outcrop East Tributary outcrop section at 105 a decimeter-scale along with ammonite fossils for biostratigraphic control (see Supplementary 106 Data). Later, a portable Shaw Backpack Drill was used to recover a continuous sequence in order 107 to perform an ultra high-resolution sampling (cm- to mm-scale) across the falling limb of the 108 carbon isotope excursion. Rock samples were subsampled for geochemical analyses using a 109 handheld Dremel tool with a diamond bit. $2 \mathrm{~N} \mathrm{HCl}$ was added to approximately $0.1 \mathrm{~g}$ of sample 110 powder and allowed to react for $\sim 24$ hours in order to remove carbonate fraction. The acid was 111 removed and sample was then brought to a neutral $\mathrm{pH}$ with multiple rinses with deionized water

112 and dried in an oven. TOC and $\delta^{13} \mathrm{C}_{\mathrm{org}}$ values of the carbonate-free residues were analyzed by an 113 Isotope Cube elemental analyzer connected to an Isoprime 100 gas source isotope-ratio mass 
114 spectrometer (IRMS) in the Department of Geosciences at Virginia Tech. Stable-isotope 115 measurements of the samples from Haida Gwaii were performed at Durham University using a 116 Costech Elemental Analyser (ECS 4010) coupled to a ThermoFinnigan Delta V Advantage (wet 117 chemical procedures were similar to those described above).

118 The isotope composition of the samples is expressed in the standard delta $(\delta)$ notation as 119 per mil deviations (\%o) from Vienna Pee Dee Belemnite (VPDB). The East Tributary samples 120 were calibrated to the VPDB scale using international (IAEA-CH-6 and IAEA-CH-7) and 121 commercial standards from Elemental Microanalysis (wheat flour, sorghum flour, low organic 122 soil, and urea). Long-term analytical precision for the $\delta^{13} \mathrm{C}$ measurements is $0.1 \%$ based on 123 replicated analyses on isotope standards: this provided a linear range in $\delta^{13} \mathrm{C}$ between $-48.66 \%$ o 124 and $-10.42 \%$. Total organic carbon was obtained as part of the isotopic analysis using internal 125 standards (i.e., Acetanilide, $71.09 \%$ C). Approximately 31\% of hand samples $(\mathrm{n}=128)$ were 126 replicated at least once; $71 \%$ of drill core samples $(n=69)$ were replicated at least once. Average 127 analytical uncertainty for replicated analyses $(n=89)$ was $0.07 \%$. For the Haida Gwaii samples 128 that were analyzed at Durham, data accuracy is monitored through routine analyses of in-house 129 standards, which are stringently calibrated against international standards (e.g., USGS 40, USGS 130 24, IAEA 600): this provided a linear range in $\delta^{13} \mathrm{C}$ between $-46.7 \%$ and $+2.9 \%$. Analytical 131 uncertainty for $\delta^{13} \mathrm{C}_{\text {org }}$ measurements is typically $\pm 0.1 \%$ for replicate analyses of the 132 international standards and typically $<0.2 \%$ for replicate sample analysis. Total organic carbon 133 was obtained as part of the isotopic analysis using an internal standard (i.e., Glutamic Acid, $134 \quad 40.82 \% \mathrm{C})$. 


\subsection{Biostratigraphy}

Here we report new biostratigraphic data from the East Tributary section (Fig. 2). The biostratigraphy of the Haida Gwaii section can be found in Caruthers et al. (2011). Specimens of Amaltheus, Protogrammoceras, and Tiltoniceras occur below the negative CIE interval at East Tributary, from 0 to $10.9 \mathrm{~m}$ (Fig. 2), and indicate a late Pliensbachian to early Toarcian age (Smith and Tipper, 1996). Of these specimens, Amaltheus, $P$. kurrianum, and $P$. skidegatense are restricted to the late Pliensbachian (Kunae and Carlottense Zones) while in western North America T. cf. antiquum, and $P$. paltum, are known to span the Pliensbachian-Toarcian boundary (Smith and Tipper, 1996). From $\sim 10$ to $16 \mathrm{~m}$ in the section, species of Dactylioceras, Cleviceras, Hildaites, and Harpoceras occur in abundance. In northwest Europe these genera are common throughout the early Toarcian Tenuicostatum and Serpentinum zones (Howarth, 1992) and in western North America they represent the larger Kanense Zone (Jakobs et al., 1994, Jakobs, 1997). Zugodactylites, Dactylioceras commune, D. athleticum, Harpoceras cf. subplanatum, Pseudolioceras $\mathrm{cf}$. lythense, Peronoceras, and Phymatoceras occur from $\sim 16$ to 22 $\mathrm{m}$ in the section (Fig. 2). Of these species, only D. athleticum and D. commune are known to span the early-middle Toarcian boundary (Howarth, 1962; Howarth, 1992), while the other taxa from this interval are restricted to the middle Toarcian Bifrons Zone from Europe and Russia or Planulata Zone of western North America (Jakobs, 1997; Howarth, 1978, 1992). These assignments agree with the recently proposed Lower Toarcian ammonite zonal schemes (e.g., Page, 2004).

\subsection{Carbon isotope chemostratigraphies}

Our new high-resolution organic carbon isotope $\left(\delta^{13} \mathrm{C}_{\mathrm{org}}\right)$ record from East Tributary 
160 shows a prominent negative CIE that occurs over 5 meters of strata within the Kanense Zone of 161 the Early Toarcian (Fig. 2). In this section, data show an overall decrease in $\delta^{13} \mathrm{C}_{\text {org }}$ values with 162 high-frequency variations from $\sim-27 \%$ to $-30 \%$ over a decimeter at the Red Deer-Poker Chip 163 Member transition (Figs. 2 and 3). Values remain at $\sim-30.5 \%$ for 1.3 meters, approaching a 164 minimum of $-30.7 \%$, before gradually increasing to $-26.8 \%$ over the next four meters. Post-CIE $165 \quad \delta^{13} \mathrm{C}_{\text {org }}$ values are relatively constant at approximately $-27.5 \%$. In the Yakoun River Section, the 166 high-resolution $\delta^{13} \mathrm{C}_{\text {org }}$ values have a positive trend immediately before the CIE (Fig. 3). On the 167 falling limb, high-frequency "steps" are present from $\sim-25 \%$ o to $-32 \%$ over a meter interval.

168 Over the next 5 meters in the Yakoun River Section, there are several $\delta^{13} \mathrm{C}_{\text {org }}$ oscillations on the 169 order of $0.5 \%$ that occur over the most negative interval of the T-OAE CIE.

\section{$170 \quad 4.3$ Total organic carbon (TOC)}

TOC values at the East Tributary location are generally between $2-6 \%$ (Fig. 2). The

172 highest values are within the early to middle part of the T-OAE CIE, before decreasing during 173 the rising limb and staying constant into the Bifrons Zone. Broadly, there is no significant 174 covariation between TOC and $\delta^{13} \mathrm{C}_{\mathrm{org}}$ values (see supplementary data table); however, during the 175 falling limb of the T-OAE CIE, there is a positive correlation between these values $\left(\mathrm{r}^{2}=0.72\right)$. 176 At the Yakoun River Section, TOC values are highest within the T-OAE CIE interval, but the 177 full range $(0.1-1.1 \%)$ is greater than that associated with values before the CIE $(\sim 0.2-0.6 \%$; 178 see supplementary data table). Also, there are two populations where TOC and $\delta^{13} \mathrm{C}_{\text {org }}$ values 179 correlate: pre-CIE interval and CIE interval.

\section{5. Discussion}

\subsection{The early Toarcian carbon isotope record}

Along with other recently published records outside of the Tethyan and Boreal regions 
183 (Al-Suwaidi et al., 2011; Caruthers et al., 2011, 2014; Gröcke et al., 2011; Suan et al., 2011;

184 Kemp and Izumi, 2014), the new biostratigraphic and $\delta^{13} \mathrm{C}_{\text {org }}$ records reported here further 185 confirm the assertion that the broader T-OAE CIE was a global phenomenon. This is compelling 186 evidence that the T-OAE CIE is an important chemostratigraphic marker, and therefore may be 187 useful as a chronostratigraphic indicator where there is limited biostratigraphic data. Importantly, 188 these new high-resolution records from western Canada document multiple, small-scale CIEs in 189 the falling limb of the overall T-OAE CIE at both locations, and indicate that these features also 190 may represent perturbations to the global carbon cycle.

Apart from the overall influence of the Karoo-Ferrar LIP on the global carbon cycle, one 192 of the more fascinating features of the T-OAE CIE is its highly dynamic falling limb. The abrupt, 193 small-scale CIEs within this interval of the overall CIE may have been generated by the 194 destabilization of methane clathrate reservoirs linked to astronomically paced changes in climate 195 (Kemp et al., 2005; Hesselbo and Pieńkowski, 2011; Hermoso et al., 2012). However, the abrupt 196 temporal nature of the small-scale CIEs has recently been challenged (Trabucho-Alexandre, 197 2014), leading to questions of whether the carbon isotope record is reflective of methane 198 clathrate destabilization. A detailed analysis of the sedimentology from one of the best-studied 199 Toarcian successions at Yorkshire in the United Kingdom suggests that the sequence contains 200 several sedimentary hiatuses that have affected the morphology of the $\delta^{13} \mathrm{C}$ record. Specifically, 201 these changes in sediment accumulation rate resulted in the abrupt or stepped appearance of the 202 small-scale CIEs (Trabucho-Alexandre, 2014) (Fig. 1). While accumulation rates, erosion, and 203 changes in sea level may have played a role in the shape of the $\delta^{13} \mathrm{C}$ datasets at Yorkshire and 204 other Toarcian successions in Europe (e.g., Hesselbo and Pieńkowski, 2011; Hermoso et al., 205 2012; Pittet et al., 2014), the similar number of small-scale CIEs between sections is evidence 

227 cycle.

that they are likely correlative and represent true perturbations to the carbon cycle.

Although sedimentary processes may influence the morphologies of the small-scale CIEs, their presence in the major exogenic carbon reservoirs (Fig. 1) suggests that they represent changes to the global carbon cycle. It has also been proposed that the small-scale CIEs are a product of variation in the mixing of different sources of organic matter (Suan et al., 2015). However, again, the occurrence of these small-scale CIEs in both carbonate carbon (Hermoso et al., 2012) and higher plant matter (Hesselbo and Pieńkowski, 2011) (Fig. 1) suggests that they represent global carbon cycle perturbations.

The high-resolution western North American $\delta^{13} \mathrm{C}$ records (Figs. 2 and 3) presented here are certainly less complete than some European records (e.g., Kemp et al., 2005; Hermoso et al., 2012). The North American successions are more condensed during the onset of the T-OAE CIE and potentially contain temporal gaps as evidenced by the abrupt jumps in the $\delta^{13} \mathrm{C}$ records (see Fig. 4 for an illustrative figure that displays the potential location of these gaps). The small-scale CIE morphologies are probably controlled by sediment accumulation rates and hiatuses (e.g., Trabucho-Alexandre, 2014), and potentially reflect changes in sea level (e.g., Pittet et al. 2014), as these sedimentary processes operating on multiple timescales play an important controlling role on the morphology of geochemical records. However, these records display similar smallscale CIEs that are likely correlative to those observed in European records (Fig 4.; Kemp et al., 2005; Hesselbo et al., 2007; Hesselbo and Pieńkowski, 2011; Hermoso et al., 2012). Therefore, based on our datasets combined with the existing European records, it is evident that during the initial phase of the CIE, there were indeed higher-frequency changes within the global carbon

These new western North American $\delta^{13} \mathrm{C}$ records are noticeably different from one 
229 another in morphology and magnitude (Fig. 3), and are likely a product of sedimentary 230 accumulation rates and preservation. The Haida Gwaii section represents a thicker succession, 231 and the small-scale CIEs during the most negative portion of the T-OAE are also apparent (Figs. 2323 and 4). The lack of small-scale CIEs during the nadir of isotope excursion in Alberta may be 233 driven by sampling resolution, as we stopped our high-resolution sampling before this interval. 234 Since accumulation rates were relatively less in Alberta, it may be possible to identify these if 235 the section is sampled at much higher resolution throughout the entire CIE (similar to the cm236 scale resolution of the T-OAE CIE onset). The magnitude of change in the Alberta $\delta^{13} \mathrm{C}$ record $237(\sim-3.5 \%)$ is smaller than that observed in the Haida Gwaii section $(\sim-6 \%)$, but is consistent 238 with compound-specific carbon isotope records that have suggested the global magnitude of the 239 T-OAE CIE is -3\% to -4\%o (Schouten et al., 2000; French et al., 2014; Suan et al., 2015).

Changes in the relative contribution of marine versus terrestrial organic matter may also 241 influence local $\delta^{13} \mathrm{C}$ records and potentially confound interpretations of global processes. 242 Comparison of the North America carbon isotope records to compound-specific carbon isotope 243 records suggests there were likely more significant changes in the source of organic matter 244 during the T-OAE in British Columbia than in Alberta. Unfortunately, the section at East 245 Tributary is thermally overmature $\left(\mathrm{T}_{\max }>500^{\circ} \mathrm{C}\right)$, thus obfuscating traditional organic 246 geochemical evaluations of organic matter sources (Riediger, 2002, Asgar-Deen, 2003). 247 However, Rock-Eval data from less thermally mature drill cores of Fernie Formation from 248 locations to the northeast of our study site have high hydrogen index (HI) values (up to $740 \mathrm{mg}$ $249 \mathrm{HC} / \mathrm{g}$ TOC) and indicate a dominantly marine source of organic matter (Riediger, 2002; Asgar250 Deen, 2003); only sites farther to the north of these have lower HIs and yield higher inert carbon 251 values, indicating an increased input of terrestrial organic matter (Riediger, 2002; Asgar-Deen, 
252 2003). This regional pattern in the organic geochemistry suggests that the East Tributary site was

253 a location of relatively limited terrigenous organic matter input. Also, while the East Tributary

254 section does shows a correlation between $\delta^{13} \mathrm{C}$ and TOC during the falling limb of the T-OAE

255 CIE, which might suggest the varying contribution terrestrial versus marine organic matter, the

256 more negative $\delta^{13} \mathrm{C}$ values across the small-scale CIEs occur during intervals with high calcium

257 carbonate contents. When TOC contents are calculated on a carbonate-free basis, the correlation

258 between $\delta^{13} \mathrm{C}$ and TOC content is lost and suggests dilution of the TOC contents by carbonate

259 accumulation. This observation, along with the fact that the overall CIE is of a similar magnitude

260 to the marine compound-specific isotope records (Schouten et al., 2000; French et al., 2014;

261 Suan et al., 2015), also suggests minimal influence of terrestrial organic matter in our Albertan

$262 \quad \delta^{13} \mathrm{C}$ records. In summary, our data when combined with other observations suggest a lack of 263 change in the organic matter source during the deposition of the East Tributary succession, and 264 therefore changes in the relative amount of marine versus terrestrial organic matter were unlikely 265 drivers of the small-scale CIEs observed at this location. This observation, combined with the 266 small-scale CIEs that appear in the $\delta^{13} \mathrm{C}_{\text {carbonate }}$ (Hermoso et al., 2012) and $\delta^{13} \mathrm{C}_{\text {phytoclast }}$ (Hesselbo 267 and Pieńkowski, 2011) records from Europe, supports notion that these small-scale CIEs 268 represent perturbations to the global carbon cycle.

\subsection{Drivers of the Toarcian carbon cycle perturbations}

271 Drawing on new observations from the North American carbon isotope records combined

272 with those from existing published datasets, we revisit the proposed drivers of the Toarcian 273 carbon isotope record. Previous studies have suggested that the T-OAE CIE may have been 274 caused by one or a combination of the following mechanism(s): efflux of mantle-derived carbon, 
275 methane hydrate destabilization, thermogenic methane release related to the emplacement of the

276 Karoo-Ferrar LIP, or $\mathrm{CO}_{2}$ from terrestrial organic matter decomposition (e.g., Hesselbo et al., 277 2000; Pálfy and Smith, 2000; McElwain et al., 2005; Svensen et al., 2007; Beerling and 278 Brentnall, 2007; Pieńkowski et al., 2016) (see Table 1) with discrete methane clathrate 279 destabilization events as the cause of the multiple, small-scale CIEs on the falling limb (Kemp et 280 al., 2005; Hesselbo and Pieńkowski, 2011; Hermoso et al., 2012). However, modeling of the 281 Toarcian carbon cycle (Beerling and Brentnall, 2007) has shown that these forcings alone do not 282 fully explain the magnitude of the T-OAE CIE and the associated climatic responses (McElwain 283 et al., 2005, Beerling and Brentnall, 2007). Simulations involving thermogenic emissions of $\mathrm{CH}_{4}$ 284 from the Karoo-Ferrar LIP also cannot reproduce the magnitude of the CIE or result in carbon 285 fluxes which vastly exceed the estimates (McElwain et al., 2005) for the increased atmospheric 286 $p \mathrm{CO}_{2}$ during the T-OAE (Beerling and Brentnall, 2007). Invoking methane clathrate 287 destabilization requires an amount of methane (>6,000 Gt C) (Beerling and Brentnall, 2007) that 288 greatly exceeds estimates of the modern clathrate reservoir ( $\sim 500-2,500$ Gt C) (Milkov, 2004); 289 and given the greenhouse climate of the Early Jurassic, the size of the standing clathrate reservoir 290 may have been substantially less. Moreover, in order to produce the short-term oscillations 291 observed in the carbon isotope record, large clathrate releases would need to be followed by 292 rapid and repeated replenishment of the marine clathrate reservoir, which is an unlikely scenario 293 excursions - the inputs of methane from terrestrial environments (e.g. wetlands, lakes, and 296 soils). For example, wetlands represent the dominant non-anthropogenic source of atmospheric methane today (O'Connor et al., 2010; Bridgham et al., 2013), and wetland methane emissions 
298 should respond significantly and rapidly to increases in global temperature (increases of up to $299 \sim 20 \%$ per $1^{\circ} \mathrm{C}$ ) and precipitation (8\% increase per $20 \%$ increase in precipitation) (Walter et al., 300 2001). Furthermore, recent reports of terrestrial carbon budgets and distributions are painting a 301 much clearer picture of its important role in the global carbon cycle (e.g., Tian et al., 2016). 302 Releases of terrestrial carbon stocks have also been proposed as a cause of extreme global 303 warming events during the early Cenozoic (e.g., Pancost et al., 2007). The Early Jurassic is 304 considered to be a greenhouse time interval with warm and humid climates (e.g., Korte et al., 305 2015), constituting ideal conditions for the formation of extensive wetlands, peatlands, swamps, 306 and inland lakes particularly at high latitudes. Therefore, we posit that global warming and the 307 enhanced hydrological cycle resulting from the eruption of the Karoo-Ferrar LIP led to a positive 308 feedback — increased methane and carbon dioxide emissions rates from terrestrial environments 309 - which led to continued warming.

310 Further, we propose that the small-scale CIEs that are present in the Toarcian carbon311 isotope records could be linked to astronomically paced changes in the climate system which 312 affected rates of terrestrial methanogenesis (e.g., changes in precipitation patterns, solar 313 insolation, etc.). However, it is important to point out that changes in terrestrial methanogenesis 314 rates and the destabilization of methane clathrates would operate on similar timescales and 315 respond to warming in a similar fashion. Therefore it is possible that these two drivers could 316 have both contributed to the shorter-term perturbations in the global carbon cycle during the 317 Toarcian.

318 Other scenarios, in which pulses of volcanogenic $\mathrm{CO}_{2}$ or thermogenic methane drive 319 these small-scale CIEs, are possible as well. Eruptions of the Karoo-Ferrar large igneous 320 province during the late Pliensbachian and Toarcian have been linked to global marine extinction 
321 events (Harries and Little, 1999; Caruthers et al., 2013). However, as with marine clathrate

322 release, the amount of carbon required from volcanic sources on such short timescales (e.g., Sell

323 et al., 2014) is difficult to reconcile (Beerling and Brentnall, 2007). Numerical models suggest

324 the release of 6,000 to $9,000 \mathrm{Gt}$ carbon derived from biogenic methane $\left(\delta^{13} \mathrm{C}\right.$ of $-60 \%$ over 220

325 kyrs can reproduce the overall magnitude and shape of the T-OAE CIE ranging from -3 to $-5 \%$

326 (Beerling and Brentnall, 2007; see Table 1). Based on a more recent 100-kyr estimation (Sell et

327 al., 2014) for the duration of the falling limb of the CIE, an increase in global average air

328 temperature of $4.5^{\circ} \mathrm{C}$ (Dera and Donnadieu, 2012), an estimated range of modern wetland

329 methanogenesis rates, $0.0691-0.210 \mathrm{Gt}$ C/year (as summarized by O'Connor et al., 2010;

330 Bridgham et al., 2013), and the response of methanogenesis rates to temperature ( $20 \%$ increase

331 per $1{ }^{\circ} \mathrm{C}$ increase based on both empirical and modeling studies) (Walter et al., 2001; Christensen

332 et al., 2003), we calculate an approximate two-fold $(\sim 2 \mathrm{x})$ increase in terrestrial methanogenesis

333 rates $(\sim 0.131-0.399 \mathrm{Gt} \mathrm{C} /$ year $)$ or an additional $0.062-0.189 \mathrm{Gt} \mathrm{C} /$ year across the T-OAE.

334 Overall this warming alone has the potential to release an additional $\sim 6,620-18,869 \mathrm{Gt} \mathrm{C}$

$335\left(8,307-25,200 \mathrm{Gt} \mathrm{CH}_{4}\right)$ from wetlands. These magnitudes represent values that are similar to or

336 much larger than what is necessary to cause and sustain the CIE (Beerling and Brentnall, 2007;

337 see Table 1).

338 If we consider the full range of air and sea surface temperature estimates for the T-OAE

339 (Dera and Donnadieu, 2012; Korte et al., 2015, and references therein) (see Table S1) combined

340 with the full range of estimates for modern methanogenesis rates (O'Connor et al., 2010;

341 Bridgham et al., 2013), then an additional 3,455 - 33,544 Gt C could have been released to the

342 atmosphere. These amounts would significantly alter the atmospheric $\delta^{13} \mathrm{C}$ composition. Note

343 that there would be a significant latitudinal gradient in warming (Dera and Donnadieu, 2012) 
344 (see Table S1) that would affect the regional methane fluxes. Proxy reconstructions and 345 modeling of sea surface and air temperature changes during the T-OAE suggest increases that 346 range from 3 to $>10^{\circ} \mathrm{C}$ (Dera and Donnadieu, 2012; Korte et al., 2015, and references therein) 347 that are highly dependent on paleolatitude; thus, there is potential for larger terrestrial methane 348 releases based on regional temperature changes (refer to SI Table 1). Further, a recent modeling 349 study suggests that there was a global increase in precipitation of $9 \mathrm{~cm} / y$ ear during the T-OAE, 350 reaching up to $10-20 \mathrm{~cm} /$ year in high latitudes and equatorial regions of Gondwana and the 351 Tethys (Dera and Donnadieu, 2012), which would have affected methanogenesis rates in 352 wetlands and other terrestrial environments (Walter et al., 2001). We only attempted to show the 353 potential temperature effects in the previous calculations. However, even fractions of the 354 amounts calculated here would release enough carbon to the atmosphere to not only alter its $\delta^{13} \mathrm{C}$ 355 composition, but also to produce significant changes in global temperatures.

356 Importantly, combining carbon fluxes from other plausible sources (mantle $\mathrm{CO}_{2}$, 357 thermogenic $\mathrm{CH}_{4}$, and clathrate $\mathrm{CH}_{4}$ ) diminish the amount needed from any individual source; 358 lesser amounts of terrestrial-derived greenhouse gases would be necessary when the other drivers 359 are involved. As multiple drivers are likely responsible for the T-OAE CIE and global warming, 360 we suggest that methane and carbon dioxide release from terrestrial environments can provide a 361 plausible and important feedback flux that fills outstanding deficiencies of previously proposed 362 Toarcian carbon cycle budgets. The flux of terrestrial carbon should be considered in future 363 refinements of carbon cycle models during climatic warm periods in the geologic record 364 following the proliferation of land plants and the widespread establishment of humic soils. 

368 documented from multiple oceanic basins spanning the globe. This is consistent with the 369 suggestion that they reflect global perturbations to the carbon cycle triggered by volcanism 370 associated with the emplacement of the Karoo-Ferrar LIP and subsequent biogeochemical 371 feedbacks (e.g. methane clathrate releases or terrestrial methanogenesis). This finding also 372 further confirms the utility of the overall T-OAE CIE as a global chemostratigraphic marker. 373 Additionally, we suggest that increased terrestrial methanogenesis, which would have been 374 important positive feedback to the initial warming and increased precipitation caused by the 375 emplacement of the Karoo-Ferrar LIP, played an important role in the Toarcian carbon cycle. 376 Importantly, any additional flux of carbon from terrestrial environments to the ocean-atmosphere 377 system would decrease the carbon flux needed from other potential sources to generate the 378 broader T-OAE CIE and small-scale CIEs within it. Future studies will further elucidate the role 379 of the terrestrial carbon cycle in the Toarcian climatic change.

A better understanding of the T-OAE record may serve to inform models of other events 381 triggered by rapid injections of greenhouse gases, such as the PETM. While these two events 382 were separated by roughly 130 million years and had significantly different Earth system 383 boundary conditions, the resulting environmental change and ecological deterioration were 384 broadly similar. As our planet experiences another significant perturbation to the global carbon 385 cycle and climatic warming, the record of environmental change recorded during these geologic 386 events represent an invaluable archive for models of future long-term climate and oceanographic 387 change. 


\section{Acknowledgements}

This work is dedicated to our late friend and colleague Russell Hall, whose work in the Jurassic of Canada stimulated this study. A grant to BCG from the NSF (EAR-1324752) funded the majority of this work. TRT would also like to thank the Geological Society of America, Society for Sedimentary Geology, and Virginia Tech Department of Geosciences graduate student grant programs for funding. RCM would like to thank a UT Austin seed grant for funding fieldwork. Thanks to Angela Gerhardt, Selva Marroquín, and Joshua Lively for their help in the field work portion of the study as well as the staff at the RTMP for fossil curation. Finally, we would like to thank associate editor Derek Vance, Mathew Hurtgen, Michaël Hermoso, and an anonymous reviewer whose comments greatly improved the manuscript. This is Natural Resources Canada Contribution No. ESS 20150492. 


\section{References}

Al-Suwaidi, A.H., Angelozzi, G.N., Baudin, F., Damborenea, S.E. Hesselbo, S.P., Jenkyns, H.C., Manceñido, M.O., and Riccardi, A.C., 2010, First record of the Early Toarcian Oceanic Anoxic Event from the Southern Hemisphere, Neuquén Basin. Arg. J. Geol. Soc. [Lon.] 167, 633-636.

Asgar-Deen, M., 2003, Stratigraphy, Sedimentology and Paleogeography of the Lower Jurassic Nordegg Member (Gordondale Member), west-central Alberta, Canada. MS Thesis, University of Calgary, Calgary, Alberta, 202 p.

Asgar-Deen, M., Hall, R., Craig, J., and Riediger, C., 2003, New biostratigraphic data from the Lower Jurassic Fernie Formation in the subsurface of west-central Alberta and their stratigraphic implications. Can. J. Earth Sci. 40, 45-63.

Beerling, D.J., and Brentnall, S.J., 2007, Numerical evaluation of mechanisms driving Early Jurassic changes in global carbon cycling. Geology 5, 247-250.

Bond, D.P.G., and Wignall, P.B., 2014, Large igneous provinces and mass extinctions: An update in Keller, G., and Kerr, A.C., eds., Volcanism, Impacts and Mass Extinction: causes and effects. Geol. Soc. Amer. Spec. Paper 505, 29-55.

Boulila, S., Galbrum, B., Huret, E., Hinnov, L.A., Rouget, I., Gardin, S., and Bartolini, A., 2014, Astronomical calibration of the Toarcian Stage: Implications for sequence stratigraphy and duration of the early Toarcian OAE. Earth Planet. Sci. Lett. 386, 98-111.

Bridgham, S.D., Cadillo-Quiroz, H., Keller, J.K., and Zhuang, Q., 2013, Methane emissions from wetlands: biogeochemical, microbial, and modeling perspectives from local to global scales. Glob. Change Biol. 19, 1325-1346.

Burgess, S.D., Bowring, S.A., Fleming, T.H., and Elliot, D.H., 2015, High-precision geochronology links the Ferrar large igneous province with early-Jurassic ocean anoxia and biotic crisis. Earth Planet. Sci. Lett. 415, 90-99.

Caruthers, A.H., Gröcke, D.R., and Smith, P.L., 2011, The significance of an Early Jurassic (Toarcian), carbon-isotope excursion in Haida Gwaii (Queen Charlotte Islands), British Columbia, Canada. Earth Planet. Sci. Lett. 307, 19-26.

Caruthers, A., Smith, P.L., and Gröcke, D.R., 2014, The Pliensbachian-Toarcian (Early Jurassic) extinction: a North American perspective, in Keller, G., and Kerr, A.C., eds., Volcanism, Impacts and Mass Extinction: causes and effects. Geol. Soc. Amer. Spec. Paper 505, 225-243.

Christensen, T.R., Ekberg, A., Ström, L., and Mastepanov, M., 2003, Factors controlling large scale variations in methane emissions from wetlands. Geo. Res. Lett. 30, 1414.

Cohen, A.S., Coe, A.L., Harding, S.M., and Schwark, L., 2004, Osmium isotope evidence for the regulation of atmospheric $\mathrm{CO}_{2}$ by continental weathering. Geology 32, 157-160. 
Cohen, A.S., Coe, A.L., and Kemp, D.B., 2007, The Late Palaeocene-Early Eocene and Toarcian (Early Jurassic) carbon isotope excursions: a comparison of their time scales, associated environmental changes, causes and consequences. J. Geol. Soc., London 164, 10931108.

Danise, S., Twitchett, R.J., and Little, C.T.S., 2015, Environmental controls on Jurassic marine ecosystems during global warming. Geology 43, 263-266.

Dera, G.D., and Donnadieu, Y., 2012, Modeling evidence for global warming, Arctic seawater freshening, and sluggish ocean circulation during the Early Toarcian anoxic event.

Paleoceanography 27, PA2211.

Dickens, G.R., O’Neil, J.R., Rea, D.K., and Owen, R.M., 1995, Dissociation of oceanic methane hydrate as a cause of the carbon isotope excursion at the end of the Paleocene. Paleoceanography 10, 965-971.

French, K.L., Sepúlveda, J., Trabucho-Alexandre, J., Gröcke, D.R., and Summons, R.E., 2014, Organic geochemistry of the early Toarcian oceanic anoxic event in Hawsker Bottoms, Yorkshire, England. Earth Planet. Sci. Lett. 390, 116-127.

Fu, X., Wang, J., Feng, X., Wang, D., Chen, W., Song, C., and Zeng, S., 2016, Early Jurassic carbon-isotope excursion in the Qiangtang Basin (Tibet), the eastern Tethys: Implications for the Toarcian Oceanic anoxic event. Chem. Geol. 442, 67-72.

Gröcke, D.R., Hori, R.S., Trabucho-Alexandre, J., Kemp, D.B., and Schwark, L., 2011, An open record of the Toarcian oceanic anoxic event. Sol. Earth Discuss. 2, 245-257.

Hall, R.L., 1984, Lithostratigraphy and biostratigraphy of the Fernie Formation (Jurassic) in the southern Canadian Rocky Mountains, in Stott, D.F., and Glass, D.J., eds., The Mesozoic of Middle North America. Can. Soc. Petr. Geol. Mem. 9, 233-247.

Hall R.L., Poulton, T.P., and Monger, J.W.H., 1998, Chapter 2 Field Trip A1: CalgaryVancouver, in Smith, P.L., ed., Field Guide for the Fifth International Symposium on the Jurassic System, Vancouver, Jurassic Subcommission of the Stratigraphic Commission of the International Union of Geological Sciences, Vancouver, 29-61.

Harries, P., and Little, C.T.S., 1999, The early Toarcian (Early Jurassic) and CenomanianTuronian Late Cretaceous, mass extinctions, similarities and contrasts. Palaeogeo. Palaeoclim. Palaeoecol. 154, 39-66.

Hermoso, M., Minoletti, F., Rickaby, R.E.M., Hesselbo, S.P., Baudin, F., and Jenkyns, H.C., 2012, Dynamics of a stepped carbon-isotope excursion: Ultra high-resolution study of Early Toarcian environmental change. Earth Planet. Sci. Lett. 319-320, 45-54.

Hermoso, M., and Pellenard, 2014, Continental weathering and climatic changes inferred from clay mineralogy and paired carbon isotopes across the early to middle Toarcian in the Paris Basin. Palaeogeo. Palaeoclim. Palaeoecol. 399, 385-393. 
Hesselbo, S.P., Gröcke, D.R., Jenkyns, H.C., Bjerrum, C.J., Farrimond, P., Morgans Bell, H.S., and Green, O.R., 2000, Massive dissociation of gas hydrate during a Jurassic oceanic anoxic event. Nature 406, 392-395.

Hesselbo, S.P., Jenkyns, H.C., Duarte, L.V., and Oliveira, L.C.V., 2007, Carbon-isotope record of the Early Jurassic (Toarcian) Oceanic Anoxic Event from fossil wood and marine carbonate Lusitanian Basin, Portugal. Earth Planet. Sci. Lett. 253, 455-470.

Hesselbo, S.P., and Pieńkowski, G., 2011, Stepwise atmospheric carbon-isotope excursion during the Toarcian Oceanic Anoxic Event (Early Jurassic, Polish Basin). Earth Planet. Sci. Lett. $301,365-372$.

Higgins, J.A., and Schrag, D.P., 2006, Beyond methane: Towards a theory for the PaleoceneEocene Thermal Maximum. Earth Planet. Sci. Lett. 245, 523-537.

Howarth, M.K., 1962, The Jet Rock Series and the Alum Shale Series of the Yorkshire Coast. Proc. York. Geol. Soc. 33, 381-422.

Howarth, M.K., 1978, The stratigraphy and ammonite fauna of the Upper Lias of Northamptonshire. Bull. Brit. Mus. (Nat. Hist.) 29, 235-288.

Howarth, M.K., 1992, The ammonite family Hildoceratidae in the Lower Jurassic of Britain. Mono. Palaeont. Soc. 145, 1-200.

Jakobs, G.K., Smith, P.L., and Tipper H.W., 1994, An ammonite zonation for the Toarcian (Lower Jurassic) of the North American Cordillera. Can. J. Earth Sci. 31, 919-942.

Jakobs, G.K., 1997, Toarcian (Early Jurassic) Ammonoids from Western North America. Geol. Surv. Can. Bull. 428, 1-137.

Jenkyns, H.C., 1988, The early Toarcian (Jurassic) anoxic event: Stratigraphic, sedimentary, and geochemical evidence. Am. J. Sci. 288, 101-151..

Kemp D.B., Coe, A.L., Cohen, A.S., and Schwark, L., 2005, Astronomical pacing of methane release in the Early Jurassic period. Nature 437, 396-399.

Kemp, D.B., and Izumi, K., 2014, Multiproxy geochemical analysis of a Panthalassic margin record of the Early Toarcian oceanic anoxic event (Toyora area, Japan). Palaeogeo. Palaeoclim. Palaeoecol. 414, 332-341.

Korte, C., Hesselbo, S.P., Ullmann, C.V., Dietl, G., Ruhl, M., Schweigert, G., and Thibault, N., 2015, Jurassic climate mode governed by ocean gateway. Nature Comm. 6, 10015.

McElwain, J.C., Wade-Murphy, J., and Hesselbo, S.P, 2005, Changes in carbon dioxide during an oceanic anoxic event linked to intrusion into Gondwana coals. Nature 435, 479-482.

Milkov, A.V., 2004, Global estimates of hydrate-bound gas in marine sediments: how much is really out there? Earth-Sci. Rev. 66, 183-197.

O’Connor, F.M., Boucher, O., Gedney, N., Jones, C.D., Folberth, G.A., Coppell, R., Friedlingstein, P., Collins, W.J., Chappellaz, J., and Johnson, C.E., 2010, Possible role of 
wetlands, permafrost, and methane hydrates in the methane cycle under future climate change: A review. Rev. Geophys. 48, RG4005.

Page, K., 2004, A sequence of biohorizons for the Subboreal Province Lower Toarcian in Northern Britain and their correlation with a submediterranean standard. Riv. Ital. Paleont. Strat., $110,109-114$.

Pálfy, J., and Smith, P.L., 2000, Synchrony between Early Jurassic extinction, oceanic anoxic event, and the Karoo-Ferrar flood basalt volcanism. Geology 28, 747-750.

Panchuk, K., Ridgwell, A., and Kump, L.R., 2008, Sedimentary response to Paleocene-Eocene Thermal Maximum carbon release, A model-data comparison. Geology 36, 315-318.

Pancost, R.D., Steart, D.S., Handley, L., Collinson, M.E., Hooker, J.J., Scott, A.C., Grassineau, N.V., and Glasspool, I.J., 2007, Increased terrestrial methane cycling at the Palaeocene-Eocene thermal Maximum. Nature 449, 332-335.

Pieńkowski, G., Hodbod, M., and Ullmann, C.V., 2016, Fungal decomposition of terrestrial organic matter accelerated Early Jurassic climate warming. Scientific Reports 6, DOI:10.1038/srep31930.

Pittet, B., Suan, G., Lenoir, F., Duarte, L.V., and Mattioli, E., 2014, Carbon isotope evidence for sedimentary discontinuities in the lower Toarcian of the Lusitanian Basin (Portugal): Sea level change at the onset of the Oceanic Anoxic Event. Sed. Geol. 303, 1-14.

Poulton T.P., and Hall, R.L. 1993, Western Interior Canada. The Jurassic of the Circum-Pacific, in Westermann, G.E.G., ed., (Cambridge University Press), 38-44.

Reidiger, C.L., 2002, Hydrocarbon source rock potential and comments on correlation of the Lower Jurassic Poker Chip Shale, west-central Alberta. Bull. Can. Petrol. Geol. 50, 263-276.

Röhl, U. Westerhold, T., Bralower, T.J., and Zachos, J.C., 2007, On the duration of the Paleocene-Eocene Thermal Maximum (PETM). Geochem. Geophys. Geosys. 8, Q12002.

Schouten, S., van Kaam-Peters, H.M.E., Rijpstra, W.I.C., Schoell, M., and Damsté, J.S.S., 2000, Effects of an oceanic anoxic event on the stable carbon isotopic composition of early Toarcian carbon. Am. J. Sci. 300, 1-22.

Scotese, C.R., 2001, Atlas of Earth History. PALEOMAP Project, Arlington, Texas.

Sell, B., Ovtcharoca, M., Bartolini, A., Jourdan, F., Spangenberg, J.E., Vicente, J.-C., and Schaltegger, U., 2014, Evaluating the temporal link between the Karoo LIP and climaticbiologic events of the Toarcian Stage with high-precision $\mathrm{U}-\mathrm{Pb}$ geochronology. Earth Planet. Sci. Lett. 408, 48-56.

Smith, P.L., 2006, Paleobiogeography and Early Jurassic molluscs in the context of terrane displacement in western Canada, in Haggart, J.W., Enkin, R.J., Monger, J.W.H., eds., Paleogeography of the North American Cordillera: Evidence for and Against Large Scale 
Displacements. Geol. Assoc. Can. Spec. Pap., 46, 81-94.

Smith P.L., and Tipper H.W., 1996, Pliensbachian (Lower Jurassic) Ammonites of the Queen Charlotte Islands, British Columbia. Bull. Am. Paleont. 108, 1-122.

Suan, G., Mattioli, E., Pittet, B., Mailliot, S., and Lécuyer, C., 2008, Evidence for major environmental perturbation prior to and during the Toarcian (Early Jurassic) oceanic anoxic event from the Lusitanian basin, Portugal. Paleoceanography 23, PA1202.

Suan, G., Nitikenko, B.L., Rogov, M.A., Baudin, F., Spangenberg, J.F., Knyazev, V.G., Glinskikh, L.A., Goryacheva, A.A., Adatte, T., Riding, J.B., Föllmi, K.B., Pittet, B., Mattioli, E., and Lécuyer, C., 2011, Polar record of Early Jurassic massive carbon injection. Earth Planet. Sci. Lett. 312, 102-113.

Suan, G., van de Schootbrugge, B., Adatte, T., Fiebig, J., and Oschmann, W., 2015, Calibrating the magnitude of the Toarcian carbon cycle perturbation. Paleoceanography 30, 495-509.

Svensen, H., Planke, S., Chevallier, L., Malthe-Sørenssen, A., Corfu, F., and Jamtveit, B., 2007, Hydrothermal venting of greenhouse gases triggering Early Jurassic global warming. Earth Planet. Sci. Lett. 256, 554-566.

Svensen, H., Planke, S., Malthe-Sørenssen, A., Jamtveit, B., Myklebust, R., Rasmussen Eidem, T., and Rey, S.S., 2004 Release of methane from a volcanic basin as a mechanism for initial Eocene global warming. Nature 429, 542-545.

Tian, H., et al., 2016, The terrestrial biosphere as a net source of greenhouse gases to the atmosphere. Nature 531, 225-228.

Trabucho-Alexandre, J., 2014, More gaps than shale: erosion of mud and its effect on preserved geochemical and palaeobiological signals, in Smith, D.G., Bailey, R.J., Burgess, P.M., Fraser, and A.J., eds., Strata and Time: Probing the Gaps in Our Understanding. Geol. Soc. Lon. Spec. Pub. 404, 251-270.

Walter, B.P., Heimann, M., and Matthews, E., 2001, Modeling Modern Methane Emissions from Natural Wetlands 2. Interannual Variations 1982-1993. J. Geophys. Res. 106, D24, 34,20734,219 .

Wignall, P.B., McArthur, J.M., Little, C.T.S., and Hallam, A., 2006, Methane release in the Early Jurassic period: Comment. Nature 442, 441. 


\section{Figure Captions}

\section{Figure 1. Global paleogeography of the Early Toarcian and high-resolution $\delta^{13} C_{o r g}$,}

$\delta^{13} C_{\text {carb }}$, and $\delta^{13} C_{\text {phytoclast }}$ records across Toarcian carbon isotope excursion (CIE). Black circles represent presence of Toarcian organic-rich facies (updated from Jenkyns, 1988; additional references provided in Table S2). Open circles represent locations where T-OAE CIE has been recognized. Hatched outline in southern Africa and Antarctica represents location and extent of Karoo-Ferrar large igneous province. Dark grey represents landmasses, light grey represents shallow seas and pericontinental terranes, and white represents open oceans. Note some circles represent multiple localities in close proximity. 1 is location of East Tributary; 2 is location of Haida Gwaii; 3 is location of Yorkshire (Hesselbo et al., 2000; Kemp et al., 2005); 4 is location of Sancerre (Hermoso et al., 2009, 2012; Hermoso and Pellenard, 2014); 5 is location of Brody-Lubienia (Hesselbo and Pieńkowski, 2011). Note the small-scale CIEs on the falling

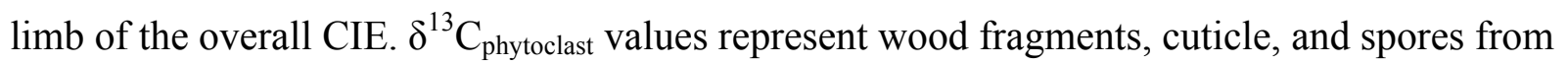
terrestrial locations. Paleogeographic map modified from (Scotese, 2001).

\section{Figure 2. Chemostratigraphy and ammonite biostratigraphy of East Tributary of Bighorn}

Creek, Alberta. $\delta^{13} \mathrm{C}_{\text {org }}=$ organic carbon isotopic compositions; TOC = total organic carbon. Lithostratigraphic members of the Fernie Formation, stages of the Jurassic, and ammonite zonations for both northwestern Europe and western North American shown to the left of the stratigraphic column (refer to the supplementary material for details of the placement of these 
zonations). Ammonite zone boundaries are noted across the data plots with dashed lines. The Pliensbachian-Toarcian stage boundary is marked with a solid line. Ten. $=$ Tenuicostatum.

Figure 3: High-resolution $\delta^{13} C_{o r g}$ records of the T-OAE CIE from western North America. (A) East Tributary of Bighorn Creek, AB, and (B) Haida Gwaii (formerly Queen Charlotte Islands), BC. In comparison to some of the European records (Fig. 1), it is clear that both sections contain a less complete record of the overall falling limb of the T-OAE CIE. Despite this incompleteness, both sections contain several small-scale CIEs (arrows). At East Tributary, these are expressed as centimeter-scale oscillations on the falling limb of the overall CIE and are likely correlative to those seen at the beginning of the CIE in Europe. At Haida Gwaii, smallscale CIEs that occur at the nadir of the overall CIE are better represented. Boxes are placed around the complete $\delta^{13} \mathrm{C}_{\text {org }}$ records to show where these high-resolution records are in context to each study site.

Figure 4: Illustrative and idealized record T-OAE CIE and the subsequent sedimentary expression of the CIE in the $\delta^{13} \mathbf{C}_{\text {org }}$ records. (A) Illustrative and idealized $\delta^{13} \mathrm{C}_{\text {org }}$ morphology of T-OAE CIE through time. (B, C, D) Illustrative plots of differing sedimentary expressions of T-OAE CIE at each location caused by variable accumulation rates and hiatuses (i.e., relative completeness of the geological record). 
Figure 1
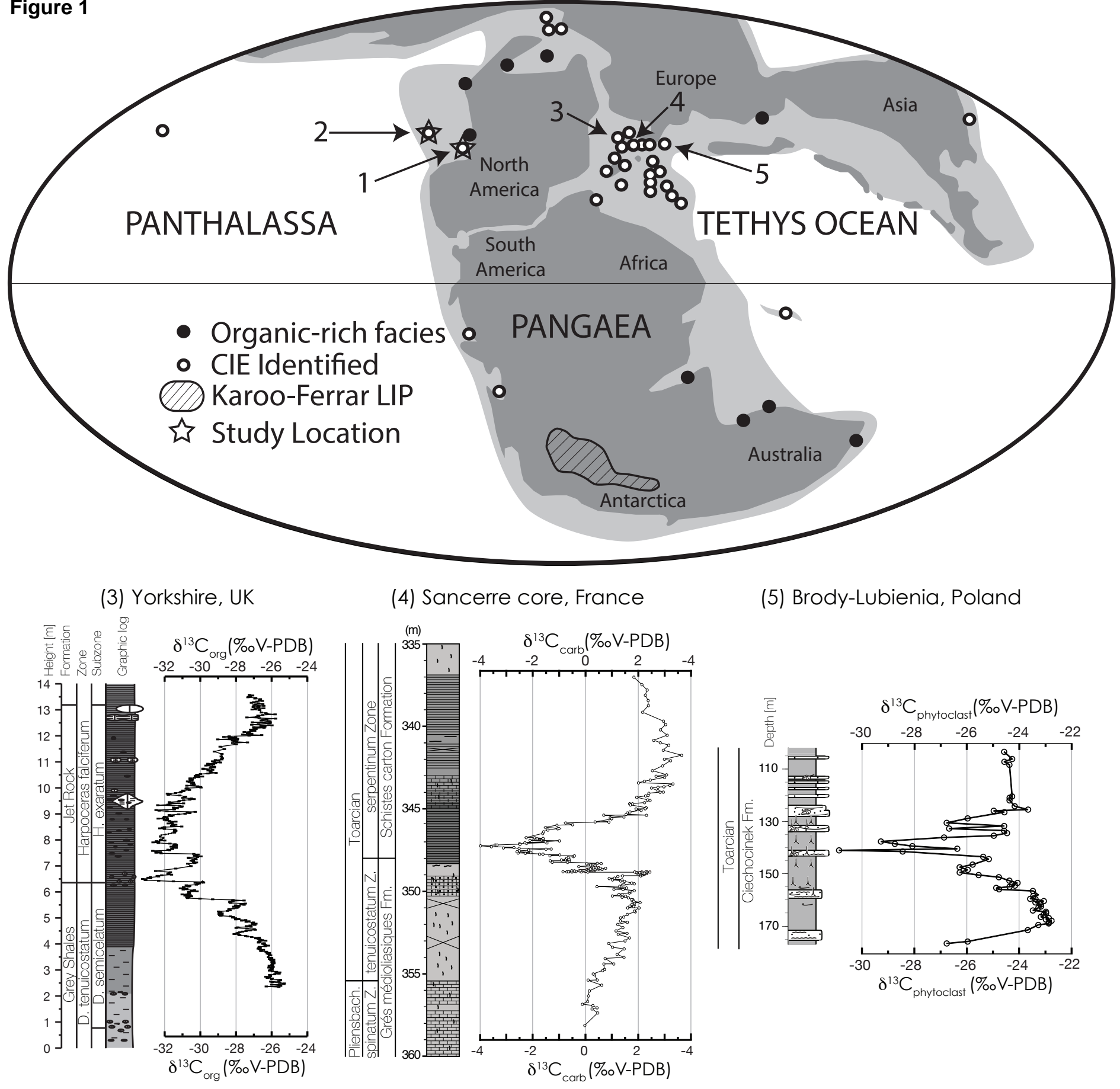

(4) Sancerre core, France

(5) Brody-Lubienia, Poland
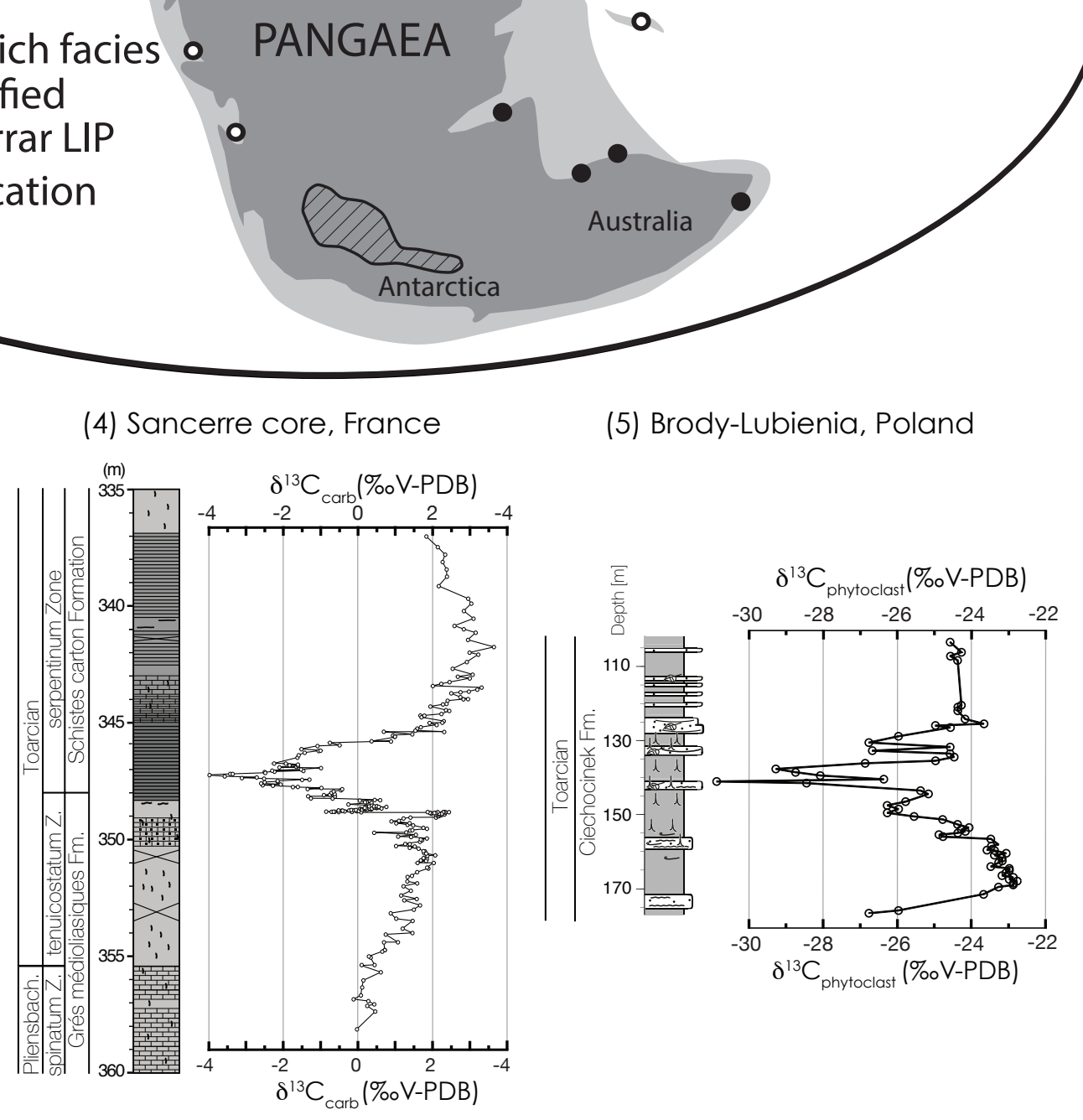


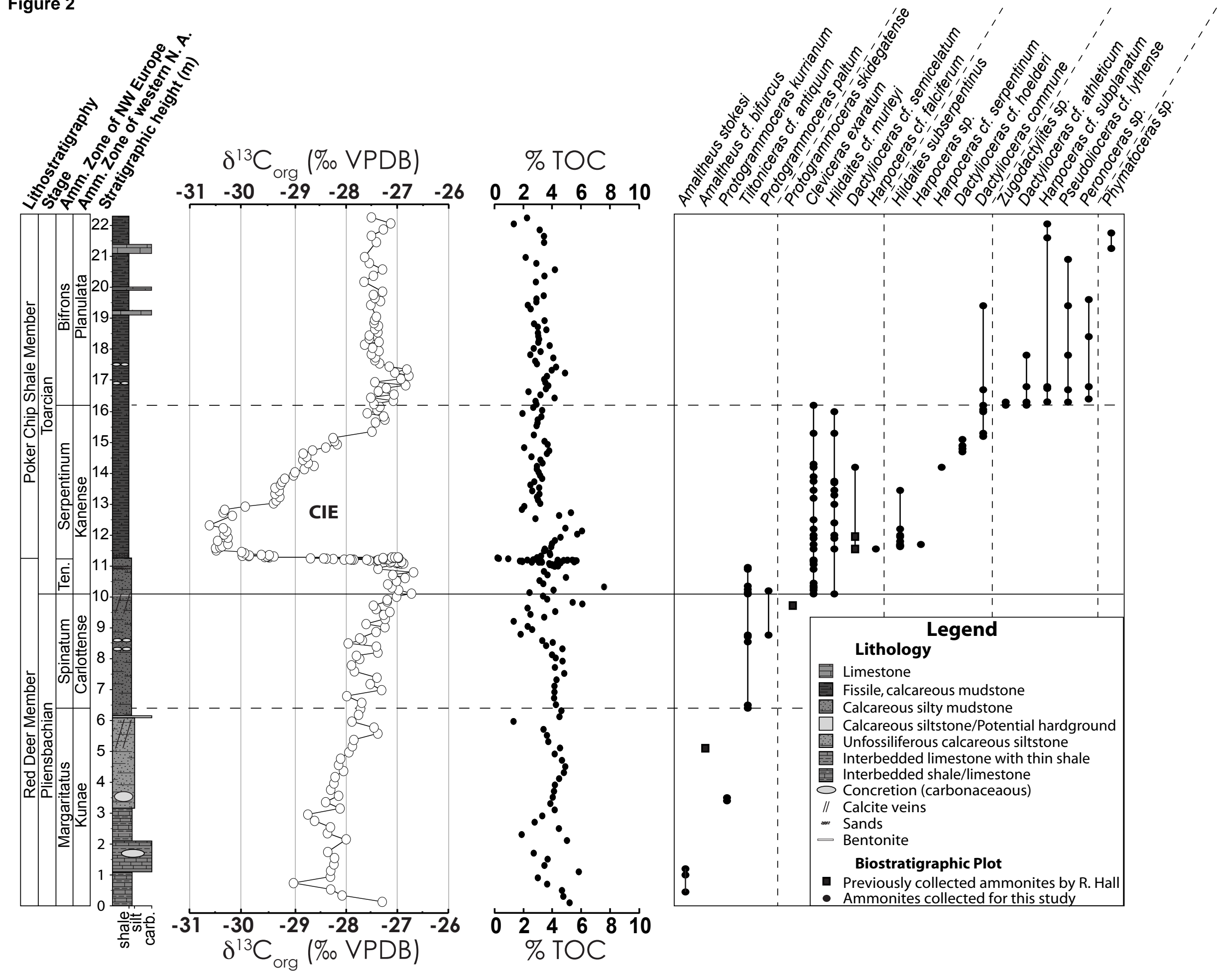



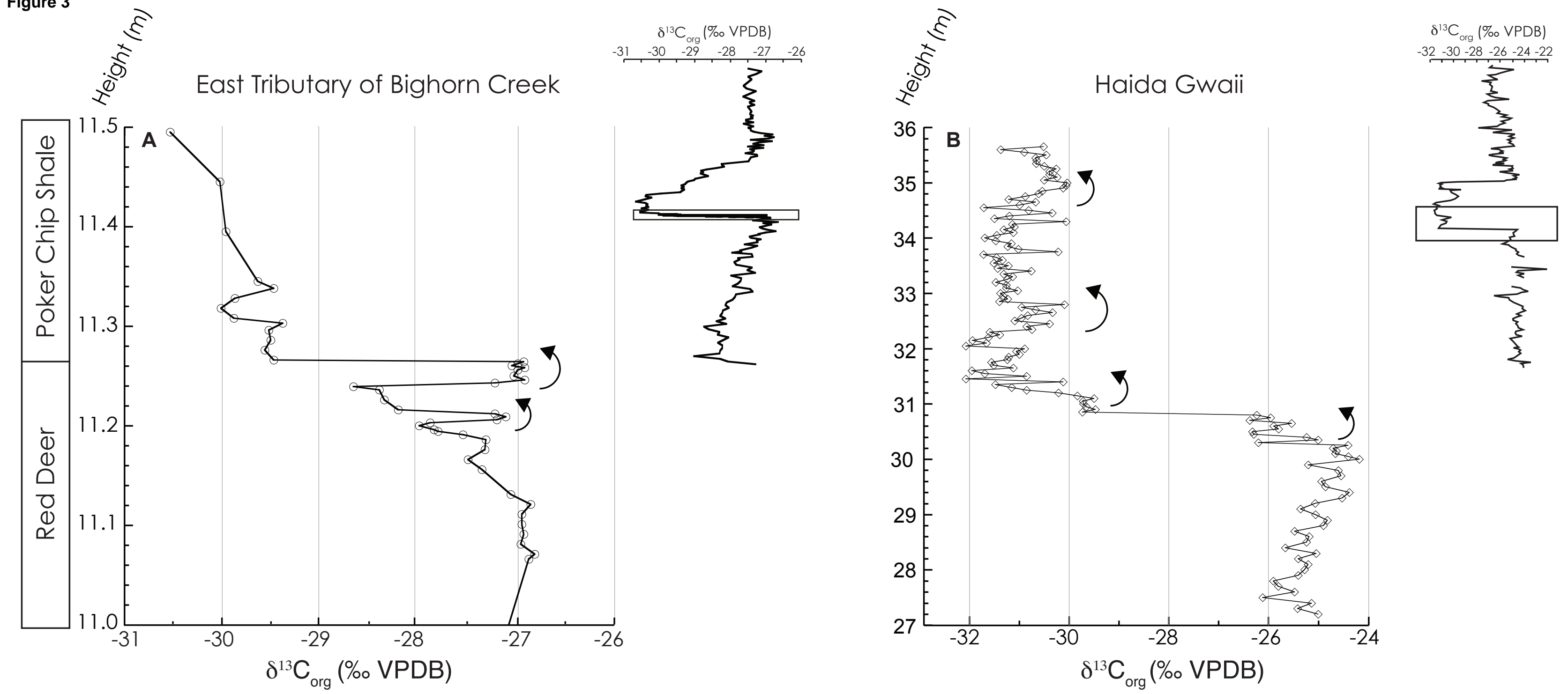
Figure 4 Idealized T-OAE $\delta^{13} \mathrm{C}$ morphology

Yorkshire Record

East Tributary Record

Haida Gwaii Record
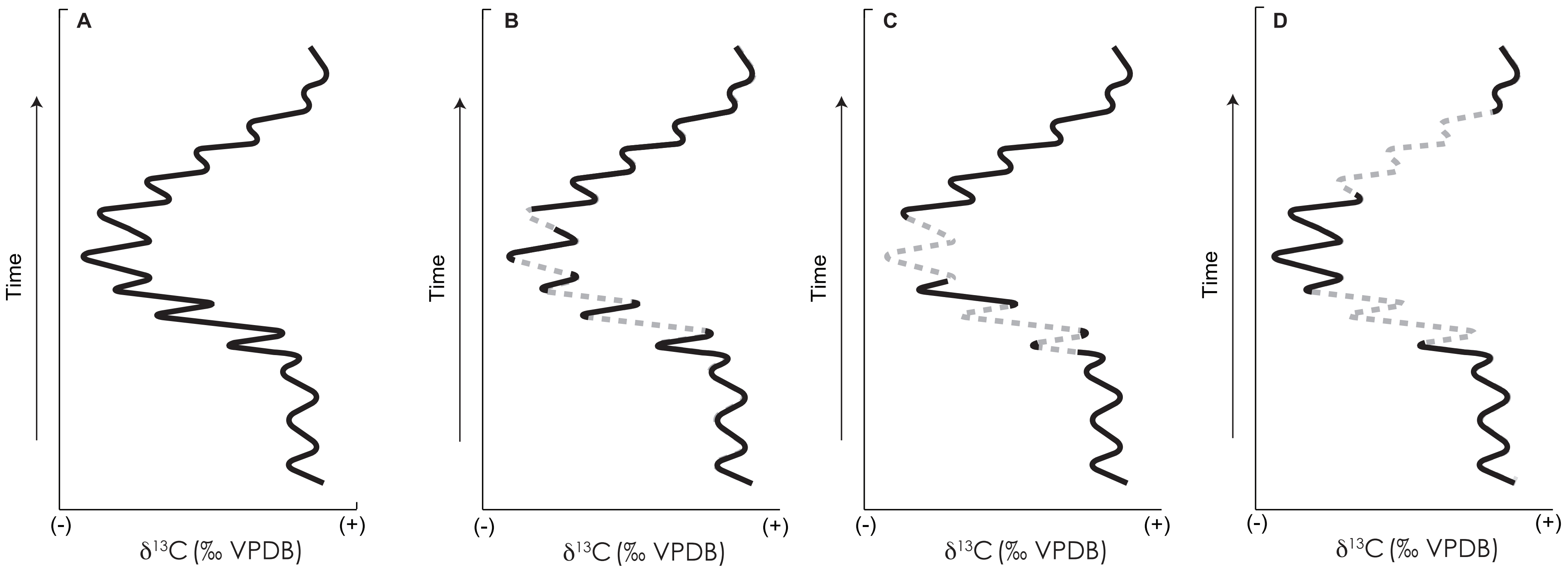
Table 1. Calculated masses of carbon associated with the Toarcian carbon isotope excursion.

\begin{tabular}{|c|c|c|c|}
\hline $\mathbf{\delta}^{\mathbf{1 3}} \mathbf{C}(\%)$ & Mass (Gt C) & Source & Reference \\
\hline-60 & $6,220-18,869^{*}$ & wetland methanogenesis & This study \\
\hline-60 & $>6,000$ & biogenic methane clathrate & $\begin{array}{c}\text { Beerling and Brentnall } \\
(2007)\end{array}$ \\
\hline-35 & $2,600-4,400$ & thermogenic methane & McElwain et al. (2005) \\
\hline-13.6 to -8.2 & 40,000 & mixture & Brazier et al. (2015) \\
\hline-5 & $15,340-24,750$ & mantle $\mathrm{CO}_{2}$ & $\begin{array}{c}\text { Beerling and Brentnall } \\
(2007)\end{array}$ \\
\hline
\end{tabular}

*This calculation is based on a global $4.5^{\circ} \mathrm{C}$ temperature increase (Dera and Donnadieu, 2012). 